\begin{tabular}{|l|c|c|c|c|c|} 
J. Tek. Ling & Vol.11 & No.3 & Hal. 409 - 416 & Jakarta, September 2010 & ISSN 1441-318X \\
\hline
\end{tabular}

\title{
GROWTH AND FATTY ACID COMPOSITION OF MARINE MICROALGA NANNOCHLOROPSIS sp IN MEDIUM ENRICHED WITH MAGNESIUM
}

\author{
J. Tri Astuti ${ }^{1)}$, Lies Sriwuryandari ${ }^{1)}$, Ekoputro Agung Putro1), T. Sembiring ${ }^{1)}$ \\ Division of Industrial and Environmental for Physic, Research Center for Physic, \\ Indonesian Institute of Sciences \\ Jalan Cisitu-Sangkuriang, Bandung 40135 \\ E-mail: jtri001@lipi.go.id \\ Hp. 08156221148
}

\begin{abstract}
Micro-algae are to be an attractive way to produce bio-diesel due to high photosynthetic yields and lipid accumulation in cells. This high productivity combined with possibility to uptake $\mathrm{CO}_{2}$ stimulated its utilization as a biological mitigation method of $\mathrm{CO}_{2}$, at once as an alternative renewable source of energy. Growth characteristics and chemical composition of micro-algae can be altered by culture environment. Nutrient sufficiency, included magnesium element $\left(\mathrm{Mg}^{2+}\right)$ is important factors on overall biochemical composition. In study, Nannochloropsis sp was cultivated in Erlenmeyer $250 \mathrm{ml}$ containing $200 \mathrm{ml} / 2 \mathrm{medium}$. There are three groups of treatment with different level of magnesium $\left(\mathrm{Mg}^{2+}\right)$, i.e. $\mathrm{O}\left(\mathrm{M}_{\mathrm{O}}\right)$; $0.1 \mathrm{mgL}^{-1}\left(\mathrm{M}_{1}\right)$; and $1.0 \mathrm{mgL}^{-1}\left(\mathrm{M}_{2}\right)$. All treatment was designed triplicate in batch system. Culture was then aerated continuously with sterile atmospheric air $\left(1.5 \mathrm{~L} . \mathrm{min}^{-1}\right)$. Cells were harvested on $25^{\text {th }}$ day after inoculation and analyzed. Data showed that Chlorophyll-a increased linearly with time and maximum at $18^{\text {th }}$ days of growth period, i.e. 23.57; 26.44; and $27.74 \mathrm{mgL}^{-1}$, for $M_{0}$; $M_{1}$; and $M_{2}$, respectively. Chlorophyll-a content decreased significantly when $\mathrm{pH}$ dropped to 5-6. Enrichment with $\mathrm{Mg}^{2+}$ increased the chlorophyll-a content 12.2-17.7\%. Dry cell reached $375-400 \mathrm{mgL}^{-1}$ in all treatment. Lipid content of Nannochloropsis sp in control $\left(M_{0}\right)$ is $55.3 \%$, higher than $M_{1}$ and $M_{2}$. Saturated fatty acid tends to increase from $80.70\left(M_{d}\right)$ to $96.70\left(M_{1}\right)$ and $94.53 \%\left(M_{2}\right)$. Fatty acid of $M_{0}$ and $M_{1}$ was composed dominantly by palmitic acid (C16:0), i.e. 49.19-70.75\% total fatty acids. Meanwhile, $M_{2}$ treatment was dominantly by lauric acid (C12:0), i.e. $32.98 \%$.
\end{abstract}

Keywords: $\mathrm{CO}_{2}$ biological mitigation, chlorophyll-a, fatty acid, lipid, magnesium, microalgae, Nannochloropsis sp, photosynthesis.

\section{INTRODUCTION}

The only ways in which a new organic carbon to be synthesized are via photosynthesis, such as in micro-algae. Micro-algae itself are eukaryotic organisms; contain chlorophyll, that serve as lightgathering molecules, making it possible to carry out photosynthesis ${ }^{1)}$. Micro-algae itself are to be an attractive way to produce bio-diesel due to high photosynthetic yields and lipid accumulation (oleaginicity) in cells ${ }^{2,3)}$. This high productivity combined with possibility to uptake $\mathrm{CO}_{2}$, stimulated its 
utilization as a biological mitigation method of $\mathrm{CO}_{2}$, at once as an alternative renewable source of energy ${ }^{4,5}$ ).

Therefore, micro-algae are the first important basis of the carbon cycle in nature ${ }^{1)}$.

It was investigated that growth characteristics and chemical composition of micro-algae can be altered by manipulation of culture environment ${ }^{6}$. Sufficient of nutrients in medium, both macro and micro-nutrients is important factors on overall biochemical composition. Macronutrient is covering of carbon, nitrogen, phosphorus, and sulfur. Micronutrient is including of potassium, zinc, iron, and magnesium ${ }^{7}$.

Magnesium $\left(\mathrm{Mg}^{2+}\right)$ has some physiological function, i.e. as an important cellular catalysts, inorganic co-factor for many enzymatic reactions, and a metal constituent of chlorophylls ${ }^{7}$. About $6 \%$ of $\mathrm{Mg}^{2+}$ element is bounded to chlorophyll. Due to the strategic position of $\mathrm{Mg}^{2+}$, all algae species requirement this element absolutely. In some algae, magnesium deficiency interrupts cell division, resulting abnormally etiolated cells. But, stress responses can be observed, both under or over supplied of $\mathrm{Mg}^{2+8}$ ).

Nannochloropsis sp is a marine microalga, which has one chloroplast in cell. Chloroplast is the sites where chlorophyll is localized and the light-gathering function involved in photosynthesis occur. This algae is only produce chlorophyll-a, not resulting chlorophyll-b and c. The main accessory pigment of Nannochloropsis is violaxanthin. The cells do not form starch ${ }^{9}$.

The previous researcher investigated that at high cell densities (109 cells $\mathrm{mL}^{-1}$ ) of Nannochloropsis gaditana, chlorophyll-a production reached $350 \mathrm{mg} \mathrm{L}^{-1}{ }^{10)}$. Another study investigated that in photoautotropic culture Nannochloropsis sp with only used $\mathrm{CO}_{2}$ from atmosphere as a sole carbon source, resulting $392 \mathrm{mgL}^{-1}$ of dry cells ${ }^{11}$.

In fact, Nannochloropsis sp is known to accumulate high level of intracellular lipids 3,12). Total lipid of Nannochloropsis sp was $28.7 \%^{13) ;} 33.3-37.8 \%^{14)} ; 10.3-16.1 \%^{15)}$. It was suggested that the production of biomass would be increased by the addition of $\mathrm{Mg}^{2}$. The aim of study is to compare the growth and lipid composition of Nannochloropsis sp that cultivated in outdoor using batch medium system with different of $\mathrm{Mg}^{2+}$ concentration.

\section{MATERIALS AND METHODS}

\subsection{Site of Experiment}

Experiment was conducted on April 2009 for 25 days in outdoor laboratory of Industrial and Environment for Physics Division, Indonesian Institute of Sciences at Bandung. The site is at $847 \mathrm{~m}$ above sea level with latitude $06^{\circ} 52^{\prime} 57.5^{\prime \prime} \mathrm{SL}$ and longitude $107^{\circ} 36^{\prime} 39.8^{\prime \prime}$ EL. In the light day, the temperature of medium was in the range of $22-39.5^{\circ} \mathrm{C}$ with average of $30.75^{\circ} \mathrm{C}$.

\subsection{Medium and Culture Condition}

The study used basal medium $\mathrm{f} / 2$, which is prepared by using salt water $3 \%$, then enriched with $8.83 \times 10^{-4} \mathrm{M} \mathrm{NH}_{4} \mathrm{NO}_{3}$; $3.63 \times 0^{-5} \mathrm{M} \mathrm{NaH}_{2} \mathrm{PO}_{4} .1 \mathrm{H}_{2} \mathrm{O} ; 1.07 \times 10^{-4} \mathrm{M}$ $\mathrm{Na}_{2} \mathrm{SiO}_{3} .9 \mathrm{H}_{2} \mathrm{O} ; 1 \times 10^{-5} \mathrm{M} \mathrm{FeCl}_{3} \cdot 6 \mathrm{H}_{2} \mathrm{O} ; 1 \times 10^{-5} \mathrm{M}$ $\mathrm{Na}_{2}$ EDTA. $2 \mathrm{H}_{2} \mathrm{O} ; 4 \times 10^{-8} \mathrm{M} \mathrm{CuSO}_{4} .5 \mathrm{H}_{2} \mathrm{O} ; 3 \times 10^{-}$ ${ }^{8} \mathrm{M} \mathrm{Na}_{2} \mathrm{MoO}_{4} .2 \mathrm{H}_{2} \mathrm{O} ; 8 \times 10^{-8} \mathrm{M} \mathrm{ZnSO}_{4} \cdot 7 \mathrm{H}_{2} \mathrm{O}$; $5 \times 10^{-8} \mathrm{M} \mathrm{CoCl}_{2} \cdot 6 \mathrm{H}_{2} \mathrm{O} ; 9 \times 10^{-7} \mathrm{M} \mathrm{MnCl}_{2} .4 \mathrm{H}_{2} \mathrm{O}$;

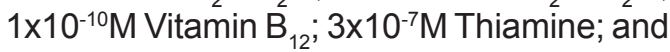
$2 \times 10^{-9} \mathrm{M}$ of Biotin.

Stock culture of Nannochloropsis $\mathrm{sp}$ was obtained from the Research Center for Biotechnology, Indonesian Institute of Sciences at Cibinong. The blue-yellowish cells Nannochloropsis sp are ellipsoidal, short and long dimensions was $2.5 \mu \mathrm{m}$ and $3.5 \mu \mathrm{m}$. The culture was maintained at laboratory in $\mathrm{f} / 2$ medium to get a high density of cell that would be used as a starter (Optical Density at $680 \mathrm{~nm} \approx 0.9-1.0$ ).

For treatment, nine units of erlenmeyer $250 \mathrm{ml}$ containing of $200 \mathrm{ml} \mathrm{f} / 2$ medium was prepared. It was ... vided into three groups with different level of magnesium $\left(\mathrm{Mg}^{2+}\right)$, i.e. 0 (without adding of $\mathrm{Mg}^{2+}$ element) as 
a control $\left(\mathrm{M}_{0}\right)$; with adding $\mathrm{Mg}^{2+} 0.1 \mathrm{mgL}^{-1}$ $\left(\mathrm{M}_{1}\right)$; and $1.0 \mathrm{mgL}^{-1}\left(\mathrm{M}_{2}\right)$. According to the treatment design, $\mathrm{Mg}^{2+}$ was added as a salt of $\mathrm{MgSO}_{4} \cdot 7 \mathrm{H}_{2} \mathrm{O}$. Then, $15 \mathrm{ml}$ of cell starter Nannochloropsis sp was inoculated. All treatment was designed triplicate in batch system.

The cultures were then incubated outdoor with natural condition, and then aerated continuously with a sterile air. Sterile air was obtained by trapping the air ambient into sulfuric acid (97-98\%), then flow it into a sterile water before inject it into the medium cultures. Aerator SP-602 with flow rate of 1.5 L. $\mathrm{min}^{-1}$ was used for this purpose. Cells were harvested on $25^{\text {th }}$ day after inoculation and then analyzed.

\subsection{Growth monitoring and lipid composition}

\section{1) Chlorophyll-a}

It was measured by first centrifuging $2 \mathrm{~mL}$ of sample at $12000 \mathrm{rpm}$ for $3 \mathrm{~min}$ (Sigma 112). Then, removed the filtrate and washed biomass pellet with $2 \mathrm{ml}$ of distilled water to rinse the adhering inorganic salts, and centrifuged again. Repeat this step for three times. Clean pellet was then extracted with $10 \mathrm{~mL}$ acetone and disrupted cells with ultrasonic for $5 \mathrm{~min}$. Concentration was calculated by absorbance at 664 and $647 \mathrm{~nm}$ using the following formula and expressed in $\mathrm{mgL}^{-1}{ }^{16)}$.

Chl-a $=\left[\left(12.64 \times \mathrm{A}_{664}\right)-\left(2.99 \times \mathrm{A}_{647}\right)\right] \times 20 \ldots$.

\section{(1)}

\section{2) Dry Cell Weight (DCW)}

The biomass was collected by first centrifuging $2 \mathrm{ml}$ of sample at $12000 \mathrm{rpm}$ for $3 \mathrm{~min}$.Removed filtrate and washed pellet with $2 \mathrm{ml}$ of distilled water to remove the adhering inorganic salts and centrifuge again. Repeat it for three times to obtain a clean pellet and dried at $70^{\circ} \mathrm{C}$ (16 hours) in oven to a constant weight. DCW was determined gravimetrically on dry weight basis, expressed in $\mathrm{mgL}^{-1}{ }^{17}$ ).

\section{3) Total lipids}

Lipid was extracted with chloroformmethanol at ratio of $2: 1(\mathrm{v} / \mathrm{v})$, then isolated the chloroform phase after adjusting solvent of chloroform: methanol: water ratio to 2:2:1. The chloroform phase (bottom) was removed in tube and evaporated at $70^{\circ} \mathrm{C}$ to dry and weight. Total lipid content was calculated gravimetrically and expressed in \% DCW ${ }^{18)}$.

\section{4) Fatty acid composition}

Lipid extract $(\approx 0.60 \mathrm{~g})$ was transmethyl-esterification with $\mathrm{BF}_{3}$. Then, methyl esters of fatty acids were analyzed using Gas Chromatography (GCMS - QP5000) equipped with Mass Spectrometry Detector and DB-17 Capillary Column (L $30 \mathrm{~m}, \varnothing$ $0.25 \mathrm{~mm}$ ). Temperatures of injector and detector were maintained at 250 and $300^{\circ} \mathrm{C}$, respectively. Temperature started at $80^{\circ} \mathrm{C}$ for $3 \mathrm{~min}$, increased by $10^{\circ} \mathrm{C} \mathrm{min}{ }^{-1}$ to $260^{\circ} \mathrm{C}$, with a final hold time for 10 min. Flow gas was $1.1 \mathrm{mLmin}^{-1}$, linear velocity was 37.5 , and pressure was $67.7 \mathrm{kpa}$. Sample $1 \mu \mathrm{L}$ was injected with splittless mode. Fatty acids were identified by comparison to NIST and Wiley Library, which was installed in the GC-MS instrument. Most compounds in accordance to the peak of GC-Chromatogram, which was offered from the library was chose as the compounds identified. Fatty acid was calculated in precentage of total fatty acid.

\section{RESULTS AND DISCUSSION}

\subsection{Chlorophyll-a}

Chlorophyll-a, is the principle of photo-chemically active compound, which functions as a receiver of light for driving photosynthesis. Amount of this pigment influences the production of biomass and accumulation of target products of 
micro-algae ${ }^{17)}$. The chlorophyll-a content of Nannochloropsis sp increased linearly with time and reached maximum at $18^{\text {th }}$ days of growth period, i.e. $23.57 ; 26.44 ; 27.74 \mathrm{mgL}^{-1}$, for $M_{0} ; M_{1}$; and $M_{2}$, respectively (Fig 1).

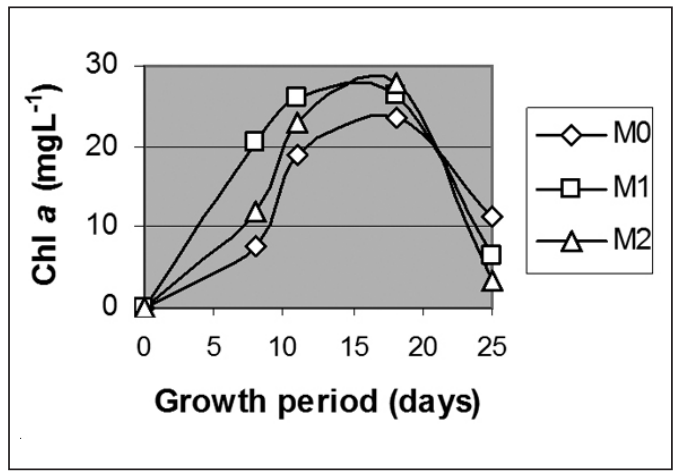

Fig $1 \mathrm{Chl}$-a content of Nannochloropsis with different concentration of $\mathrm{Mg}^{2+}$

This pattern is similar with the previous research result ${ }^{10)}$. Nevertheless the concentration of chlorophyll-a, that resulting is this study is lower. It was reported that Nannochloropsis gaditana produced chlorophyll-a 260.0; 209.2; and $349.1 \mathrm{mgL}^{-1}$ for $6^{\text {th }} ; 9^{\text {th }}$; and $14^{\text {th }}$ of culture day ${ }^{(10)}$. In contrast, another study reported that chlorophyll-a Nannochloropsis oculata was 2.7-20.8 mg/g DCW ${ }^{17)}$. By using the same unit with this reference, chlorophyll-a in this study is higher, i.e. 27-127 $\left(\mathrm{M}_{0}\right)$; 17.4-206.6 $\left(\mathrm{M}_{1}\right)$; and 9.8-152.6mg/g DCW $\left(\mathrm{M}_{2}\right)$.

Enrichment of growth medium with $\mathrm{Mg}^{2+}$ element would increase the chlorophyll-a formation, i.e. $12.2-17.7 \%$. Nevertheless, in growth period of $18^{\text {th }}$ to $25^{\text {th }}$ day, chlorophyll-a content in all treatment decrease significantly, i.e. to $11.5\left(\mathrm{M}_{0}\right) ; 6.5\left(\mathrm{M}_{1}\right)$; and $3.4 \mathrm{mg} \mathrm{L}^{-1}$ $\left(\mathrm{M}_{2}\right)$, that might be as indicator of stationary phase.

It was investigated ${ }^{19)}$ that the reaction mixture on the reduction rate of chlorophyll-a formation was affected by $\mathrm{pH}$, which $\mathrm{Mg}^{2+}$ removal from chlorophyll-a occurred under acidic conditions $(\mathrm{pH}<5)$. The same characteristic was showed in study where $\mathrm{pH}$ decreased from 7 to 6 , mainly for $M_{2}$ (Fig 2).

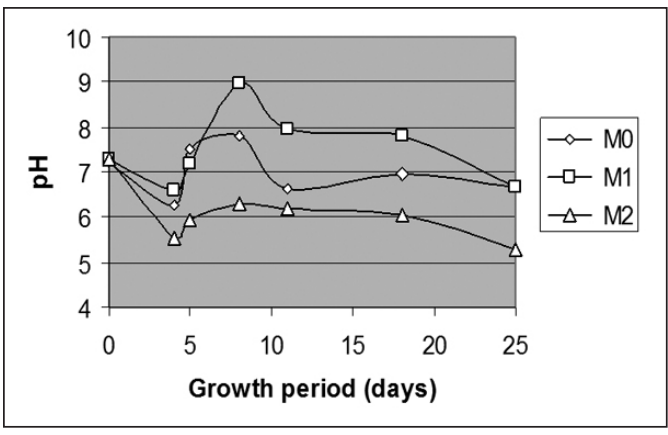

Fig $2 \mathrm{pH}$ of Nannochloropsis culture in medium with different concentration of $\mathrm{Mg}^{2+}$

In fact, temperature of medium during study was $22-37^{\circ} \mathrm{C}$ that might be caused disturbance to chlorophyll-a production. It was reported, chlorophyll synthesis is most rapid in between $26-30^{\circ} \mathrm{C}^{10}$ ). The reduction rate of chlorophyll formation was investigated increased with increasing of temperature. Bleaching of culture occurred when temperature near to $40^{\circ} \mathrm{C}^{19)}$, which also happened in study.

\subsection{Dry Cell Weight (DCW)}

The whole carbon cycle of phototrophically organisms is builtwhen the rate of photosynthesis exceed the rate of respiration. In this condition, some of carbon that fixed from $\mathrm{CO}_{2}$ will become as the starting material for biosynthesis. As the result, the organism grow, and the cell number or biomass increase ${ }^{(1)}$. Data showed biomass of increased linearly with time (Fig 3 ).

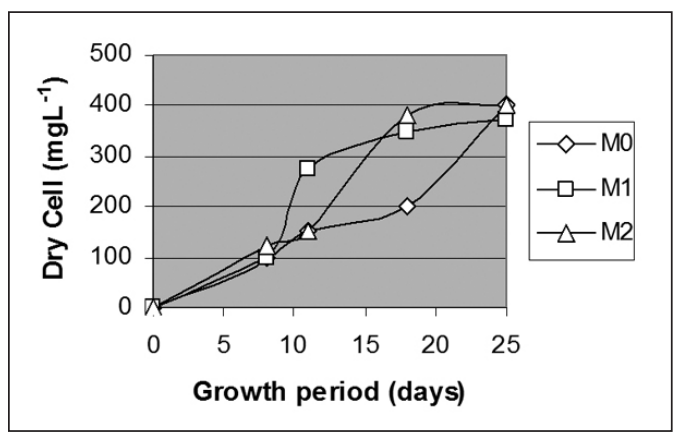

Fig 3 Dry cell production of Nannochloropsis $\mathrm{sp}$ with different concentration of $\mathrm{Mg}^{2+}$ 
In the $18^{\text {th }}$ day, production of dry cell are 200; 350; and $400 \mathrm{gL}^{-1}$ for $\mathrm{M}_{0}$; $\mathrm{M}_{1}$; and $\mathrm{M}_{2}$, respectively. It indicates that enrichment of $\mathrm{Mg}^{2+}$ element in growth medium affected to the rate of biosynthesis of micro-algae. Nevertheless, the production of cell biomass at the $25^{\text {th }}$ day was suggested in stationary phase that reached $375-400 \mathrm{mgL}^{-1}$. This result is equivalent with the previous studies, i.e. $392 \mathrm{mgL}^{-1}{ }^{11)} ; 300-500 \mathrm{mgL}^{-1}$ of dry cell ${ }^{4}$.

\subsection{Total lipid content (\%DCW)}

Several micro-algae strains have ability to accumulate large quantity of lipid in cell (oleaginicity). It varies with environmental condition, which is making it to be a potential indicator of the physiological state of these organisms ${ }^{17)}$. Data showed that lipid content of Nannochloropsis sp is 55.3; 9.5; and $10.5 \%$ based on dry cell for $M_{0} ; M_{1}$; and $M_{2}$, respectively (Fig 4).

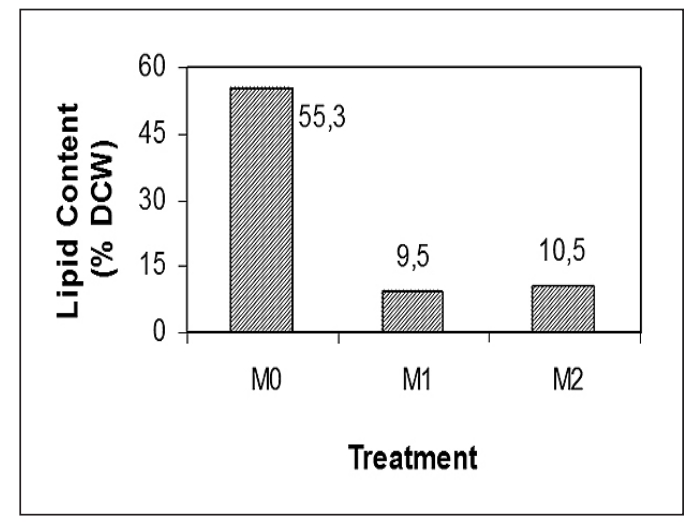

Fig 4 Lipid content of Nannochloropsis sp in medium with different concentration of $\mathrm{Mg}^{2+}$.

Total lipid in control treatment $\left(\mathrm{M}_{0}\right)$ is higher than the previous studies results, i.e. $32.1^{11)} ; 28.7^{13)}$; 33.3-37.8 ${ }^{(14)} ; 38.13 \%{ }^{(17)}$ based on dry cell weight. The lipid content of Nannochloropsis sp in control $\left(\mathrm{M}_{0}\right)$ is $55.3 \%$, higher than $\mathrm{M}_{1}$ and $\mathrm{M}_{2}$ treatment.

Alteration of lipid content might be as a response of micro-algae cell to the environmental stresses. It was suggested that the decreasing of lipid content in $M_{1}$ and $M_{2}$ treatment was caused by the excess concentration of $\mathrm{Mg}^{2+}$ in growth medium due to its toxic effect to micro-algae cell. As described before, stress responses can be observed, both under or over supplied of $\mathrm{Mg}^{2+}{ }^{7,8)}$. According to the implementation purpose of Nannochloropsis sp cultivation, enrichment of medium with $\mathrm{Mg}^{2+}$ element was not necessary due to its sufficient availability in basal medium.

\subsection{Fatty acid composition}

The chemical composition of micro-algae can be altered by its culture environment, included nutrients availability in growth medium are important factors on overall biochemical composition (6,7). Table 1 presented that composition of fatty acids Nannochloropsis sp was affected by the concentration of $\mathrm{Mg}^{2+}$. Fatty acid of Nannochloropsis sp in control medium $\left(\mathrm{M}_{0}\right)$ is dominated by saturated fatty acids $(80.70 \%)$, which covering of lauric acid (C12:0) $19.64 \%$, myristic acid (C14:0) $11.87 \%$, and palmitic acid (C16:0) 49.19\% based on total fatty acids. The rest (19.30\%) is oleic acid (C18:1n9), a monounsaturated fatty acid,

Fatty acid composition of Nannochloropsis $\mathrm{sp}$ is changed after its medium enriched with $\mathrm{Mg}^{2+}$ element. Saturated fatty acid tends to increase from 80.70 to $96.70\left(\mathrm{M}_{1}\right)$ and $94.53 \%\left(\mathrm{M}_{2}\right)$. In addition, the fatty acid composition became more variation. Compared to control, $M_{1}$ treatment resulting some other fatty acids, i.e. tridecanoic acid (C13:0) 3.23\%; pentadecanoic acid (C15:0) $3.77 \%$; and stearic acid (C18:0) $3.49 \%$ of total fatty acids. Again, some shorter chain fatty acids was produced in $M_{2}$, which covering of caprylic acid (C8:0), pelargonic acid (C9:0), capric acid (C10:0), and undecanoic acid (C11:0). Fatty acid of $M_{0}$ and $M_{1}$ was composed dominantly by palmitic acid (C16:0), meanwhile $M_{2}$ was dominated by lauric acid (C12:0). 
Table1. Fatty acids composition of Nannochloropsis $\mathrm{sp}$ in different concentration of $\mathrm{Mg}^{2+}$ (\%total fatty acids)

\begin{tabular}{|c|c|c|c|c|c|c|c|}
\hline \multirow{2}{*}{$\begin{array}{l}\text { Scientific Name } \\
\text { of Fatty Acids }\end{array}$} & \multirow{2}{*}{$\begin{array}{l}\text { Common } \\
\text { Name }\end{array}$} & \multirow{2}{*}{ Formula } & \multirow{2}{*}{$\begin{array}{c}\mathrm{C} \\
\text { atoms }\end{array}$} & \multirow{2}{*}{$\begin{array}{c}\text { Mol. } \\
\text { Weight }\end{array}$} & \multicolumn{3}{|c|}{ Treatment } \\
\hline & & & & & $M_{0}$ & $M_{1}$ & $M_{2}$ \\
\hline n-Octanoic * & Caprylic acid & $\mathrm{C}_{8} \mathrm{H}_{16} \mathrm{O}_{2}$ & C8:0 & 144 & - & - & 1.57 \\
\hline n-Nonanoic* & Pelargonic acid & $\mathrm{C}_{9} \mathrm{H}_{18} \mathrm{O}_{2}$ & C9:0 & 158 & - & - & 11.05 \\
\hline n-Decanoic* & Capric acid & $\mathrm{C}_{10} \mathrm{H}_{20} \mathrm{O}_{2}$ & C10:0 & 172 & - & - & 8.35 \\
\hline Undecanoic* & Undecanoic & $\mathrm{C}_{11} \mathrm{H}_{22} \mathrm{O}_{2}$ & C11:0 & 186 & - & - & 5.86 \\
\hline n-Dodecanoic* & Lauric acid & $\mathrm{C}_{12} \mathrm{H}_{24} \mathrm{O}_{2}$ & C12:0 & 200 & 19.64 & 5.11 & 32.98 \\
\hline Tridecanoic* & Tridecanoic & $\mathrm{C}_{13} \mathrm{H}_{26} \mathrm{O}_{2}$ & C13:0 & 214 & - & 3.28 & 3.28 \\
\hline Tetradecanoic ${ }^{*}$ & Myristic acid & $\mathrm{C}_{14} \mathrm{H}_{28} \mathrm{O}_{2}$ & C14:0 & 228 & 11.87 & 10.30 & 10.72 \\
\hline Pentadecanoic* & Pentadecanoic & $\mathrm{C}_{15} \mathrm{H}_{30} \mathrm{O}_{2}$ & C15:0 & 242 & - & 3.77 & - \\
\hline Hexadecanoic* & Palmitic acid & $\mathrm{C}_{16} \mathrm{H}_{32} \mathrm{O}_{2}$ & C16:0 & 256 & 49.19 & 70.75 & 20.72 \\
\hline Octadecanoic* & Stearic acid & $\mathrm{C}_{18} \mathrm{H}_{36} \mathrm{O}_{2}$ & C18:0 & 284 & - & 3.49 & - \\
\hline 9-Octadecenoic ${ }^{* *}$ & Oleic acid & $\mathrm{C}_{18} \mathrm{H}_{34} \mathrm{O}_{2}$ & C18:1 & 282 & $19.30-$ & 3.30 & 5.47 \\
\hline \multicolumn{5}{|l|}{ Saturated Fatty Acid ${ }^{*}$} & 80.70 & 96.70 & 94.53 \\
\hline \multicolumn{5}{|c|}{ Unsaturated Fatty acid** } & 19.30 & 3.30 & 5.47 \\
\hline
\end{tabular}

The previous studies reported the main fatty acids of Nannochloropsis sp in photoautotroph culture are palmitic acid (C16:0), palmitiolic acid (C16:1n7), oleic acid (C18:1n9), and EPA (C20:5n5, 8, 11, $14,17)$, which covering of $24.6 ; 30.2 ; 11.0$; and $21.8 \%$ of total fatty acids ${ }^{(11)}$; and another study resulted $27.5 ; 25.1,10.0$; and $21.9 \%$ of total fatty acids, respectively ${ }^{(20)}$.

\section{CONCLUSSION}

Chlorophyll-a content of Nannochloropsis $s p$ increased linearly with time and reached maximum at $18^{\text {th }}$ days of growth period, i.e. 23.57; 26.44; and $27.74 \mathrm{mgL}^{-1}$, for $M_{0} ; M_{1}$; and $M_{2}$, respectively. Chlorophyll-a content was decreased significantly when pH was dropped to 5-6. Enrichment of growth medium with $\mathrm{Mg}^{2+}$ element would increase the chlorophyll-a formation $12.2-17.7 \%$. Dry cell reached $375-$ $400 \mathrm{mgL}^{-1}$ in all treatment. Lipid content of Nannochloropsis sp in control $\left(\mathrm{M}_{0}\right)$ is $55.3 \%$, higher than $M_{1}$ and $M_{2}$ treatment. The best result was obtained in treatment without enrichment with $\mathrm{Mg}^{2+}$. Saturated fatty acid tends to increase from 80.70 to $96.70\left(\mathrm{M}_{1}\right)$ and $94.53 \%\left(\mathrm{M}_{2}\right)$. Fatty acid composition is changed after its medium enriched with $\mathrm{Mg}^{2+}$ element. Fatty acid of $\mathrm{M}_{0}$ and $\mathrm{M}_{1}$ was composed dominantly by palmitic acid (C16:0), i.e. $49.19-70.75 \%$ total fatty acids. Meanwhile, $\mathrm{M}_{2}$ treatment was dominantly by lauric acid (C12:0), i.e. 32.98\%.

\section{ACKNOWLEDGEMENTS}

This study was funded by The Competitive Research Program of Indonesian Institute of Sciences (LIPI) in field of New and Sustainable Energy. Grateful to Dr. Dwi 
Susiloningsih from Research Center for Biotechnology-LIPI for the providing culture. Great appreciation is aimed to the late Ambar Susilorukmi M.Eng for her excellent guidance.

\section{REFERENCES}

1. Madigan M.T, Martinko, JM., and Parker, J. (2000). Biology of Microorganisms. Ninth edition. Prentice Hall International, Inc. pp. 601-603

2. Lardon L, Helias A, Sialve B, Steyer JP, \& Bernard O. 2009. Life-cycle assessment of biodiesel production from microalgae. Policy Analysis. Environmental Science \& Technology. 43 (17): 6475-6481.

3. Ratledge C. 2002. Regulation of lipid accumulation in oleaginous microorganisms. Biochem Soc Trans 30: 1047-1050

4. Wang B, Li $\mathrm{Y}, \mathrm{Wu} \mathrm{N}$, and Lan CQ. 2008. $\mathrm{CO}_{2}$ bio-mitigation using micro algae. Applied Microbial Biotechnology 79:707-718.

5. Christi Y. 2007. Biodiesel from microalgae. Biotechnol Adv 25:294-306

6. Brown MR, Jeffry SW, Garland CD. 1989. Nutritional aspects of microalgae used in Mari culture: A literature review. CSIRO, Marine Laboratories Report 205, CSIRO Australia, 1-44

7. Stanier R.Y., Adelberg E. A., and Ingraham J.L. 1983. General microbiology. $4^{\text {th }} \mathrm{Ed}$. The Macmillan Press Ltd. Hongkong. Pp. 28-29.

8. Becker E. W. 1994. Microalgae: Biotechnology and Microbiology. Cambridge University Press. p.301
8. Hoek C. V.D., Mann D.G., and Jahns H.M. 2002. Algae: An introduction to phycology. Cambridge University Press. pp. 7-8; 131-133

9. Lubian LM, Montero O, Garrida IM, Huertas IE, Sobrino C, Gonzales, M \& Parés G. 2000. Nannochloropsis (Eustigmatophyceae) as a source of commercially valuable pigments. Journal of Applied Phycology 12: 249255.

10. Fang X., Wei C., Ling CZ. and Fan O. 2004. Effects of organic carbon sources on cell growth and eicosapentanoic acid content of Nannochloropsis sp. Journal of Applied Phycology 16:499-503.

11. Zou N., Zhang CW., Cohen Z., Richmond A. 2000. Production of cell mass and eicosapentanoic aced (EPA) in ultrahigh cell density cultures of Nannochloropsis sp. Eur J Phycol 35: 127-133

12. Gouveia L and Oliveira AC. 2008. Microalgae as a raw material for biofuels production J. of Industrial Microbiology \& Biotechnology. 10.1007/s10295-0080495-6

13. Fabregas J, Maseda A, Dominguez A, and Otero A. 2004. The cell composition of Nannochloropsis sp change under different irradiances in semi continuous culture, World Journal of Microbiology \& Biotechnology 20 (1):31-35.

14. Mourente G, Lubian LM, and Odriozola JM. 1990. Total fatty acid composition as a taxonomic index of some marine micro-algae used as food in marine aquaculture. Hydrobiologia 203:147154.

15. Grobbelaar JU \& Kurano N. 2003. Use of photo-acclimation in the design of a 
novel photobioreactor to achieve high yields in algal mass cultivation. Journal of Applied Phycology 15: 121-126

16. Su $\mathrm{CH}$, Fu CC, Chang YC, Nair GR, Y JL, Chu IM, and Wu WT. 2008. Simultaneous estimation of chlorophyll a and lipid content in microalgae by three-color analysis. Biotechnology and Bioengineering, Vol. 99, No. 4. p: 1034-1039

17. Bligh EG, Dyer WJ. 1959. A rapid method of total lipid extraction and purification. Can. J. Biochem. Physiol. 37: 911-917.
18. Tomonou Y \& Amao Y. 2002. Photoinduced $\mathrm{H}_{2}$ production with $\mathrm{Mg}$ chlorophyll-a from Spirulina and colloidal platinum by visible light. Biotechnology Letters 24: 775-778

19. Hu H \& Gao K. 2003. Optimation of growth and fatty acid composition of unicellular marine picoplankton, Nannochloropsis sp with enriched carbon sources. Biotechnology Letters 25:421-425. 